\title{
PUTTING AN END TO THE TRAGEDY OF RANCHING IN NAPOLEON WRASSE FISHERY IN INDONESIA: A SOCIOLOGICAL APPROACH
}

\author{
by \\ Siti Arieta \\ Department of Sociology, Faculty of Social and Political Sciences, Universitas Maritim Raja Ali Haji, \\ Tanjungpinang, Kepulauan Riau \\ Email: arietasiti@umrah.ac.id
}

\begin{tabular}{|c|c|}
\hline Article Info & ABSTRACT \\
\hline Article history: & This study aims to look into Napoleon wrasse ranching in Anambas Islands Regency. \\
\hline Received Nov 18, 2021 & Historically, the society in Anambas Islands has been socially constructed an \\
\hline Revised Dec 22, 2021 & unsustainable view of exploiting marine resources. In Napoleon wrasse fishery, \\
\hline Accepted Jan 24, 2022 & $\begin{array}{l}\text { overfishing has played a significant role in the loss of its populations. Due of the lack } \\
\text { of adult Napoleon wrasse stock in marine ecosystem, larvae despite its high mortality } \\
\text { rate are also sought as ranching target. It is found a tremendous amount of larvae are }\end{array}$ \\
\hline Keywords: & wasted in ranching period due low survival capacity to adapt to a caged ecosystem, so \\
\hline Overfishing; Conservation And & effectiveness of larvae ranching is questianable. Larvae fishing has become \\
\hline Management; Napoleon & blays an \\
\hline Wrasse; The Commons; & been more important. The reflection to establish sustainable view is seen from \\
\hline Sustainable Fisheries & $\begin{array}{l}\text { discussion between Agent-Structure theory by Bourdieu and Agent-Network Theory } \\
\text { by Latour. Local capacity to perform Locally Managed Marine Areas (LMMA) } \\
\text { created major initiatives in delivering sustainable coral reef ecosystems which also } \\
\text { form a natural environment of Napoleon wrasse }\end{array}$ \\
\hline
\end{tabular}

This is an open access article under the CC BY-SA license.

\author{
Corresponding Author: \\ Siti Arieta \\ Department of Sociology, Faculty of Social and Political Sciences, Universitas Maritim Raja Ali Haji, \\ Tanjungpinang, Kepulauan Riau \\ Email: arietasiti@umrah.ac.id
}

\section{INTRODUCTION}

Globally, overfishing has been collapsing marine resources leading to scarcity and extinction ((Luyapaert et al., 2018; Pomeroy et al., 2016; Roberson et al., 2020). Fortunately, this condition has successfully attracted world attention to create efforts in managing marine resources towards sustainability. Studies have shown that managing fisheries is deliver through restrictions and quota (do Val et al., 2019; Lowerre-Barbieri et al., 2019), but existing policies are insufficient to prevent marine resources for market demands still become a threat to marine resources. Social scholars have been contributing to develop discussion on fisheries management, putting fishery communities as responsible actor to overfishing, where it is considered not only as market failure, but also as community failure (Jentoft, 2000).

The idea of anomie reflects a society with inadequate social cohesiveness and moral norms, resulting in a failure to preserve fish stocks, resulting in a tragedy of the commons (Hardin, 1968). Within overfishing context, this system leads to collective social action failing to preserve marine resources for future need since fishermen turn to individual profit seeker. This circumstance gives rise to two options: the first is to maintain the 'anomie,' while the second is to change the systems of interdependence into fisheries management through the role of fishermen's organizations (Jentoft, 2000, 2007).

In order to discontinue overfishing practices and prevent marine resources from vanishing, conservation and management strategy is urgently needed. These issues have been discussed previously from different perspective (Pitcher \& Lam, 2010). Social-ecological system approach is believed has become a proper framework to perform conservation and resource management, including fisheries (Barnes et al., 2019; Colding \& Barthel, 2019). Ostrom 
(1990, 2009) developed an integrated framework on Social Ecological Systems (SES) that includes resource systems and units, governance systems, and as essential subsystems, with access to knowledge and institutional arrangements being significant determinants in decision making (Gurney et al., 2019; Botto-Barrios \& Saavedra-Diaz, 2020).

Other researchers have made the problem more intriguing by suggesting that conservation and management necessitate collective action (Bodin, 2017) and collaboration between scientists, environmental groups, and resource users (Lynch et al., 2017; Sherman et al., 2018). It is emphasized that conservation and management would fail owing to low governance ability and lack of support from communities (Kockel et al., 2019), implying that changing local collective behavior requires a governance regime with a set of contextual institutional arrangements (Shin et al., 2020). These organizational performances should be transparent in order to restrain anthropic tendencies among resource consumers and promote sustainability (Aswani et al., 2018; Davis \& Hanich, 2020).

Consequently, organizational capacity has become an important factor in fisheries conservation and management. Previous studies are limited to the current fisheries organizational capacity, in the meantime, organizing social reflection to develop changes towards sustainable fisheries is merely discussed. Therefore, how sustainability can reflect as new practices is important to discuss as it would show the strategy of fisheries organization to end overfishing.

Discussions on organizational capacity and its role in conservation and management are also expected to avert the loss of marine resources. One such example is the collapse of the coral reef ecosystem in order to preserve fish stocks. Coastal communities rely on the coral reef environment, however the fact that reef fisheries have been overfished has resulted in actions that contradict what was expected that these communities would have conserved their coral reef ecosystem (Barnes et al., 2019). Clearly, the high prices given in the Live Reef Fish Trade have encouraged these communities to engage in excessive fishing (Sadovy de Mitcheson et al., 2018).

Napoleon wrasse is a reef endangered fish that is in high demand and is regarded as a valuable fish in the Hong Kong market, nonetheless conserving this species has always become a paradox. There is mandate to protect this species from extinction, at the same time international trade with minimum of weights is permitted (CITES, 2017; IUCN, 2004). Such example in Anambas islands district, Indonesia, protection on Napoleon wrasse has been worsened by means of a poor management on its populations. As a consequence, the adult species is very uncommon to find in coral reef ecosystem yet prohibition to take the larvae until it reaches minimum size is abandoned (Sadovy de Mitcheson, 2019). However, stakeholders involved in Napoleon wrasse fishery seem to be effortless to replenish Napoleon wrasse natural stock in coral reef ecosystem.

Our study will discuss the reflective ability to transform the failure of thinking into new practices aiming to sustain the coral reef ecosystem through organizing LMMA performed by the Batu Belah community in Anambas islands District, Indonesia. The findings from this study provide contributions for future guidance of Locally Managed Marine Area (LMMA) as collective actions to involve more heterogeneous actors to build healthier coral reef ecosystems as these efforts bring inevitable impact to Napoleon wrasse conservation and management.

\section{LITERATURE REVIEW}

\section{Overcoming the Tragedy of the Commons}

The concept of the tragedy of the commons shapes the assumption that no occupancy of natural resources or open-access tenure system entitles everyone to take control. As a consequence, the competition will occur in maximizing the use of resources without any restrictions. This condition describes a system that traps anyone unable to hold back in using resources according to their capacity. Sooner or later, the limitations of nature to provide for human needs will be proven along with the depletion of these shared resources (Berkes \& Folke, 1992).

In response, Hardin (1968) offered private ownership of natural resources as the solution. However, this controversial concept has also received criticism through 'the benefits of the commons' stating that the Hardin model confuses common property resources with open access leading to overexploitation meanwhile the commons is compelled by social pressure to constraint individual interest (Berkes et al., 1989). As a result, the commons are community ownership managed by social groupings who assert rights of ownership over governance by prohibiting other entities from the usage of natural resources. Some norms and principles control the allocation of resource exploitation permits among this group (Korten, 1987; Berkes, 2012). Not only does it show that self-interest is not dominant, but subsistence community also raises the ability to work together in creating institutions with its function to avert a tragedy of the commons As a result, this type of communal ownership reflects particular methods for ensuring equitable access distribution.

The emergence of community-based management has shown many techniques for overcoming issues to natural resources (Gardner et al., 1990). To tackle challenges, the commons management has demonstrated subtractability through self-organization and self-regulation(Berkes, 2006). However, resource users at higher stages than the commons have a significant influence on community-based management; hence, this management requires a larger 
International Journal of Social Science (IJSS)

Vol.1 Issue.5 February 2022, pp: 817-828

ISSN: 2798-3463 (Printed) | 2798-4079 (Online)

DOI: https://doi.org/10.53625/ijss.v1i5.1333

strategy that emphasizes social learning and employs a variety of collaborative and adaptive management experiments (D. Armitage et al., 2008; Berkes, 2006).

The effort to cooperate between the state and the community in marine resource management will optimize institutional arrangements with reciprocal advantages while masking deficiencies. Co-management and Locally Managed Marine Area (LMMA) are two examples of existing collaborative practices in marine resource management. There is no definitive paradigm for co-management and LMMA because it is situation dependent (Jentoft, 1989; Jupiter et al., 2014; Kawaka et al., 2017). These two collaborative models should not be viewed as a single method for resolving fisheries management issues, but rather as a dynamic and adaptive approach in resource management.

From the government side, the response has always been positive as the state has recognized and provided management support to carry out communally (Chuenpagdee \& Jentoft, 2018). This recognition brings positive impact to marine and fisheries management to minimize homogeneous actors involved. However, the State or the community marine resources management faces its inadequacy for strict supervision, including the mechanism for sanctions against free riders from community members.

Ostrom (1991) states an aspect of caution of applying sanction as it usually increases the severity of the offense. To ensure heterogeneous actors are involved in marine resources management, stakeholder's institutional arrangement and organizational capacity are required (Carlsson \& Berkes, 2005; Pomeroy et al., 2016). Institutional arrangements through the development of technical procedures for monitoring non-conformist behavior and conflict resolution are more essential in comparison to sanction mechanisms (Ostrom, 1990).

Institutions consist of rights and rules that encourage group members to take certain actions in achieving goals. The institutional arrangement acts as a guide for actors in their relation to resources. An institution is not similar to an organization, whereas an organization operates institutional arrangements (Bromley, 1992). The institution gives more space to fishermen as they are often categorized as marginal (Carlsson \& Berkes, 2005). Institution increases fishermen's capacity in solving problems as it gives a sense of security to put initiatives in any public discussion. Through decent institution, any threat in addressing criticism and idea towards management policies is minimized. Institutions are also a forum for developing organizations, networks, and coalitions for cooperation and coordination.

According to Armitage et al. (2009), an organization is an endogenous factor that runs through various capital, specifically human capital (skills, knowledge, health), social capital (trust, networks, and reciprocity), resource capital (stocks in nature and environmental services), and physical capital (infrastructure and goods). Individual characters are also playing important roles such as leadership quality, emotion, determination, interpersonal skills, and experience will greatly influence this management process (Jentoft, 1989). Intentionally, organizational process would enhance sustainable ethics, avoid managerial silence and also develop new resource of power to establish collaboration between state and traditional management.

However, connecting heterogeneous actors in different knowledge systems, accompanied by institutional barriers in carrying out marine resource management, is a challenge that requires a need for bridging organizations. The developing definition of a bridging organization is a forum or institution that uses a specific mechanism such as a working group that connects and facilitates interaction and translates knowledge between individual actors in management (Berkes \& Folke, 1992; Armitage et al., 2009).

\section{RESEARCH METHOD}

We applied qualitative methodology with an ethnographic approach. We blended with large numbers of ranchers and fishermen in some villages involved in Napoleon wrasse fisheries (Air Sena, Piabung, Putik, Ladan, Batu Belah) from May 2019 to December 2020 to explore the challenges on conservation and management in Napoleon wrasse fishery in Anambas Islands comprehensively. Primary data was collected through observation and interviews.

Observations were conducted in various places such as ranching sites, residential areas, organizations, local government, shallow waters of the coral reef ecosystem, and larvae point in sargassum season. In addition, in-depth interviews were delivered to 36 interviewees representing stakeholder groups. Interviewees were selected through purposive sampling with specific criteria as seen in Table 1.

Table 1. Interviewees' characteristic

\begin{tabular}{lcc}
\hline Interviewees' Criteria & Number & $\begin{array}{c}\text { Age } \\
\text { Range } \\
\text { (Years) }\end{array}$ \\
\hline Government Policymakers & 8 & $35-56$ \\
Grow out ranchers (including exporter) & 10 & $35-65$ \\
Short term ranchers (including larvae catcher) & 11 & $27-40$ \\
Local community members & 6 & $20-40$
\end{tabular}

Journal homepage: https://bajangjournal.com/index.php/IJSS 


\begin{tabular}{lcc} 
Private sector (oil \& gas company) & 1 & $40-50$ \\
Total & 36 & \\
\hline
\end{tabular}

Source: Authors.

The criteria of the interviewees, as presented in Table 1, were not randomly determined but rather by considering their knowledge in Napoleon wrasse fisheries for the past 15 years. The information gathered in this study was ultimately in-depth according to the objective of the study. Interviews were organized for 45-120 minutes. The purpose of the interviews was to seek information about the history and experience of Napoleon wrasse ranching and to dig the willingness to perform conservation and sustainable Napoleon wrasse fisheries.

The interviews with the government pointed out the changes in policy and regulations to export and conservation. The interviews with ranchers, both grow out and post-settlement ranchers, emphasized the interest to participate in Napoleon wrasse ranching with quota limitation and their view to establishing sustainable fisheries. Furthermore, the interviews with local communities focused on the given support to the fisheries. An interview with the private sector indicated the hesitation to be involved in the fisheries through the scheme of Corporate Social Responsibility. The integration of gathered information provides the pattern of trade, point of view, and commitment of involved actors in the Napoleon wrasse fisheries.

Secondary data consist of various documents about Napoleon wrasse fisheries. The sources are monitoring reports, government reports, research reports, photos, and videos related to Napoleon wrasse fisheries in the Anambas Islands regency in particular. Written data described the history including numbers of exported fishes before Napoleon wrasse becomes an endangered species until nowadays where conservation is highly encouraged. Photos and videos expose the fact that Napoleon wrasse fisheries have become the favorite source of livelihood in the Anambas Islands Regency. These secondary data are remarkably essential in strengthening the findings of the study, as they contributed to the closure of the fact of overfishing and previous destructive fishing practices and how these related to existing behavior and commitment to implement conservation and sustainable management.

Both primary and secondary data were analyzed using Creswell (2013) linear and hierarchical models with its six stages including processing and preparing raw data for analysis, reading data and build a general sense and reflection, coding, linking the setting, category, informants, and theme, finally- to give interpretation or meaning to the data.

\section{FINDINGS AND DISCUSSION Findings}

Anambas Islands Regency has been designated as a national Marine Protected Area (KKPN), also known as a Marine Tourism Park (TWP), under Ministerial Decree of Marine Affairs and Fisheries Republic Indonesia No. 35 since 2011. This measure has had no substantial influence on improving the sustainability of its marine resources, since the Marine Rapid Assessment in 2013 revealed considerable degradation of the coral habitat (Mustika et al., 2013). Napoleon wrasse, in particular, has been formally designated as an endangered species due to dramatic population reductions.

Prior to the establishment of the MPA, massive quantities of Napoleon wrasse were traded in the Live Reef Food Fish Trade (LRFFT) from Anambas to Hongkong. Despite a decline in export volume from 35 tons between 2001 and 2012 to 12 tons in 2013, 6.5 tons in 2014, and 5 tons in 2018, the fate of this species has remained grim (KKP, 2015). As a result of this fisheries activity, adult fish supplies have grown progressively depleted (Edrus et al., 2012; CITES, 2016). Furthermore, since the 1990s, Napoleon wrasse larvae have been overfished due to excessive harvesting and ranching for four to five years (Soemodinoto et al., 2013).

The Ministerial Decree of Marine and Fisheries Affairs Republic of Indonesia No. 13/Kepmen-KP/2013 on Protecting Napoleon wrasse by limiting catches to a minimum of 1 kilogram for each head was the most current regulation in Indonesia aimed at ensuring sustainable Napoleon wrasse fisheries. Unfortunately, this was not properly applied until a year later, when the Ministerial Decree of Marine and Fisheries Affairs Republic of Indonesia No. 56/Kepmen-KP/2014 on Moratorium on Licensing of Fisheries Business was passed, barring foreign vessels from accessing Indonesian seas.

From 2015 to 2017, this regulation effectively ended Napoleon wrasse shipments to Hong Kong. Even though the government abolished the export restriction in 2018, it only allowed a limit of 5000 heads. Ranchers have been frustrated by this situation since they have a large number of stock transactions that have been halted for two years. Furthermore, as the number of grow out ranchers has declined, this has had an influence on the shifting patterns of ranching. A shorter period of ranching, or post-settlement ranching, is associated with sentiments of financial security since ranchers were given greater choice when selling fish to grow out ranchers (Soemodinoto et al., 2013; BPSPL, 2015).

Post-settlement ranching exploded not only because it requires less capital-due it only requires one $1 \mathrm{~m}^{2}$ cage for a maximum of 150 numbers of 2-3 inches larvae-but also because larvae grow faster in a ranched ecosystem rather 
International Journal of Social Science (IJSS)

Vol.1 Issue.5 February 2022, pp: 817-828

ISSN: 2798-3463 (Printed) | 2798-4079 (Online)

DOI: https://doi.org/10.53625/ijss.v1i5.1333

than in their natural habitat. Eight months of ranching produces 2 inches larvae and one and a half years ranching, a 3 inches. Post-settlement ranchers also do not deal with the stress of pending transactions due to the minimum export quota. Therefore, though post-settlement ranching has a much greater appeal at the same time it puts Napoleon wrasse conservation at a proportionally higher risk.

Soemodinoto et al. (2013) were able to undertake an economic assessment that demonstrated rancher inequality, demonstrating that only long-term ranchers and exporters gain from the market. Despite the fact that this study concluded that post-settlement ranching is indeed not financially viable, locals have continued to operate them. Shortterm ranchers are ignorant of their disadvantaged position in the fishing sector. Ranching has lasted for about four decades since ranchers primarily seek to raise their earnings and social standing, as this fish has always had the highest price among the LRFFT.

The fact that instant benefit has become an overriding motive for post-settlement ranchers, the legislation has not provided any synchronous regulation to the sanctioning of larvae seizing. The idea of applying subsidy as a replacement of income in the conservation of species has also never been delivered to Napoleon wrasse fisheries in Anambas Islands Regency due to no exact number of larvae catchers. Without any fallback action, larvae seizing with its high price would remain attracted to a high level of participation as this would further bring the extinction to Napoleon wrasse.

These larvae are sought in the shallow waters during the sargassum season from September to January each year. Whoever can swim - mostly male - would take parts considering this activity only requires $1.5 \mathrm{~mm}$ size net, and perforated bottle. Larvae are sold in guarantee mechanisms, whereas payment is made after two weeks if the larvae are alive but this system cannot be applied to 1-2 weeks old larvae. Even though there is a common knowledge that the 12 weeks old larvae are vulnerable, they are caught immensely by larvae fishers since the larger size of larvae are usually rare.

It is astonishing to see that just $12-20 \%$ of the whole capture of 1-two weeks immature larvae remained in the ranched habitat (Mujiyanto et al., 2020). It demonstrates that every 5 tons of exported fish equates to 5000 adult-sized larvae, so that the poor survival rate corresponds to the estimate that showed that 20.000 to 36.667 larvae were discarded in every 5 tons of ranched fish. As a result, it is critical to recognize the extent of larvae ranching inefficiency and to explore the alternative of retaining the larvae in their natural environment.

Further scientific study has revealed that 1 inch larvae - comparable to 1 year old - had an 80-90 percent greater survival rate in ranched fisheries than 1-2 weeks old larvae (BPSPL, 2013). This startling fact has been empirically ignored by the primary involved actors. They believed allowing larvae to continue to grow in natural habitat means letting the number reduced by predators. Ranching, they claimed, is the only way to save the species. This faulty thinking has formed habitual practices and at the same time demonstrating the tragedy of the commons (Hardin, 1968) in Napoleon wrasse fisheries.

This bitter fact shows the negligence of Anambas Islands society in performing sustainable fisheries since targeting larvae for seizure does not align with the objective of marine conservation (Khasanah et al., 2020). Even though the experience showed that Anambas Islands Regency had performed Napoleon wrasse larvae seizing moratorium in 2012, this effort discontinued. At the beginning of 2013, massive larvae seizing re-performed, and most catchers reported a lower number of catches than before the moratorium. Previously during peak season in January each year, a fisherman was able to catch minimum a thousand larvae but in 2013 the numbers had declined to 15-20 larvae/day equivalents to 465 - 620 larvae/month (BPSPL, 2013).

Considering the low number of larvae catches as a threat to economic benefit, this collective greed has proven the tragedy of the commons in Napoleon wrasse fisheries. Furthermore, there has been a widespread denial of larvae's instinctive ability to seek out new environments and grow organically, rather than justifying the larval fishing by stating the quantity difference between before and after moratorium as being devoured by predators. This natural probability should be studied as a fundamental assumption to preserve Napoleon wrasse instead of strengthening the faulty thinking that leads to extinction.

Furthermore, the capacity of fishermen organizations in the Anambas Islands Regency has been discernibly weak since it has been used only for an administrative requirement to receive government aid, such as fishing equipment. Nevertheless, a solid organizational capacity through a collaborative project between village administrative agencies and fishermen was established to implement the national program 'Fisheries Area Access Management' (PAAP). This program has become a source for building ecological awareness by spreading the values of Preserve, Manage, and Use sustainably of fisheries resources.

The pilot project was implemented from 2014 to 2017 across 12 villages in Indonesia. Batu Belah village was chosen to represent the Riau Islands province. This program had brought a higher state of initiative proven by the establishment of Batu Belah Bersatu (3B), a coastal monitoring group on overfishing eradication based on Village 
Regulation in 2016. Batu Belah's organizational capacity as reconversion has impacted formal structures to establish a zoning system within MPA assigning closed core zone intending to restore the degraded coastal and marine environment.

Remarkably, the Ministry of Fisheries and Marine Affairs has designated Teluk Mensabang in Batu Belah water territory as a core zone in 2017. This is a gesture of appreciation towards the village capacity to perform the 3B monitoring group to perform a Locally Managed Marine Area (LMMA). This marine management undoubtedly provides a healthier coral reef ecosystem and inevitably brings a positive impact for Napoleon wrasse as in early 2020, Batu Belah fisherman caught adult Napoleon wrasse from the surrounding waters outside Teluk Mensabang. The most important thing, LMMA would prevent the larvae from being caught and limit individual greed through organizational capacity.

\section{Discussion}

Even though the state authority has been governing the Napoleon wrasse trade, it seems to have failed to curb the open access in larvae seizing practices. Napoleon wrasse larvae fishing grounds are treated as common-pool resources (CPR) as this is where collective greed is most distressing.

In the 1990-s, destructive fishing in the Anambas Islands waters was dominated by massive cyanide use (Milner et al., 2013). This method caused extensive destruction to coral reef ecosystems. Squirted cyanide became a method to catch adult Napoleon wrasse (Sadovy de Mitcheson, 2019). Due to the practice throughout history, destructive fishing has become a foundation to habitus and reflects the understanding, thoughts, and interests of Anambas Islands society to see the world of fisheries.

It is important to underline the history and perception on fishery practices has been influencing Napoleon wrasse ranching to reproduce the greediness through faulty thinking. This condition reflects what Foster (2013) called environmental metabolic rift, described as cracked and imbalance relation between human, society, and environment due to over-exploitation resulting scarcity of resources. Without any serious commitment to recovery, the tragedy of Napoleon wrasse ranching will continue to worsen.

The conversation and management of Napoleon wrasse requires an integration of ecological, economic, and social forces. Ranching will not only erase a tremendous number of Napoleon wrasse but also reduce the availability of small fishes as a food chain to the ranched species; this has been recognized as the paradox of ranching (Klinger \& Naylor, 2012). Therefore, Napoleon wrasse ranching will also affect the food security of other subsistence fishing communities disassociate with Napoleon wrasse fisheries on a broader scale.

As economic interest has become prevalent, the predominant role of Napoleon wrasse as keystone species has been neglected(Sadovy et al., 2004). Napoleon wrasse is well known for being a predator to reef depleting and toxic species, such as the crown of thorns starfish, but other varieties of an invertebrate (Weng et al., 2015). Therefore, the disappearance of Napoleon wrasse has become a sign of unhealthy coral reef habitats. Besides, its longevity (30 years) but slow breed (after 5-10 years), and inability to reproduce in an artificial ecosystem has made larvae ranching the most profound threat to its continued survival (Sadovy de Mitcheson et al., 2020).

The collective actions on larvae seizing and ranching shows personal failure in predicting benefit from any action. This individual hindrance to self-transformation is due to the dispossession of rational choice (Hayes, 2020). However, Bourdieu proposes that individual possesses the ability to produce a reflection through reflexivity and to influence other(Bouzanis \& Kemp, 2020; Caetano, 2017; Wacquant, 2001).

Latour (1999) elaborates more on individual freedom and experience to cognitively influence others and construct collective experiences as unconsciousness transformation (Buzelin, 2005). Even though they happened to oppose each other, but they both expressed the importance of agency.

Appropriately, the Napoleon wrasse ranching describes post-settlement ranchers seem too complacent with recent earnings without being able to estimate the future ecological loss. This collective unawareness has complied and strengthens the reflection on inequality in ranching practices. This condition should herald the idea of change for post-settlement ranchers, as it will give a higher bargaining position to perform changes in ranching practices.

Social-Ecological System in natural resources management in seeing the access to knowledge as one of the fundamental factors to the decision-making process in finding a solution to the occurring problems. Berkes et al. (1994) agrees with the essential partnership between traditional knowledge and the worldview to natural resources management. Bridging two levels of knowledge would invigorate the trust and respect of involved agencies (Berkes, 2012). Without any guarantee of successful collaboration, this trial and error process leads to the enhancement of organizing and institutional capacity (Armitage et al., 2009).

The overall challenges for conserving Napoleon wrasse and managing the industry could be transformed through social learning to build up organizational capacity. Social learning as knowledgeable resource refers to the individual process of gaining knowledge and learning from each other and further understanding through reflection 
International Journal of Social Science (IJSS)

Vol.1 Issue.5 February 2022, pp: 817-828

ISSN: 2798-3463 (Printed) | 2798-4079 (Online)

DOI: https://doi.org/10.53625/ijjss.v1i5.1333

(Armitage, 2008; Jentoft, 2007). By applying social learning, the transformation of experience and awareness changing will form a continuous process include to involve marginal groups in the natural resources management.

The social learning on managing LMMA through the 3G group of Batu Belah village, though it is indirectly aiming to end the tragedy of ranching in the Napoleon wrasse fishing industry, showing the reflection towards sustainability. This organizational capacity shows the development of new experience and knowledge to the establishment of new social construction towards marine conservation. Social commitment on implementing LMMA has proven a new commitment to fisheries practices. In line with the organizing process, increasing organizational capacity becomes the key factor to successful natural resources management.

Even though LMMA in Anambas is only performed by Batu Belah village, but it involves heterogeneous actors such as fishermen, college students, local figures, village administrators, and the State. It shows the willingness and collective actions as the most needed factors in the successful of natural resources management (Acheson, 2006). Therefore, it is a great hope that LMMA would be adopted by other villages as a scheme to the changing behavior of broader society.

Finally, LMMA will transform Napoleon wrasse fisheries without prohibiting the whole ranching practices as a source of livelihood, as the expectation is to limit the fishing ground of seizing juveniles. As Carlsson and Berkes (2005) state that every structure requires domination, LMMA in Napoleon wrasse fisheries does not see dominating agencies as a threat due to the capacity of the dominated agencies to perform sustainable marine management.

\section{Conclusion}

Performing organizational capacity has led the opportunity to end the tragedy of ranching in Napoleon wrasse fishery. Organizational capacity establish new practices become the ultimate precondition in transforming Napoleon wrasse ranching as. With its continuous demand, restriction in ranching practices would never work so management becomes the only opportunity. Reflexivity and its further organizational strategy reflect the Locally Managed Marine Area (LMMA) as a new form of management involving heterogeneous actors.

LMMA designated by the Ministry of Marine Affairs and the implementation to monitoring the Marine Protected Area (MPA) is run by the community. In Anambas Islands Regency, LMMA formal structure is known in zoning system within MPA assigning closed-core zone intending to restore the degraded coastal and marine environment. Teluk Mensabang LMMA shows organizational processes carried out by the Batu Belah community through the 3B group in performing monitoring in the closed-core zone. This can be said to be an opportunity in forming a new habitual in fisheries behavior.

Even though LMMA is not specifically addressed to preserve Napoleon wrasse, it prohibits anything to be seized, including Napoleon wrasse larvae as the target for ranching. Therefore, the reflexivity through LMMA would provide the establishment of sustainable behavior not only for the benefit of Napoleon wrasse but broader coral reef species. In LMMA, numbers of Napoleon wrasse larvae would naturally grow into adult species instead of being ranched. The livelihood of the ranchers possibly continues with seeking ranching targets outside LMMA. It is a hope that Teluk Mensabang LMMA can become adaptive learning for other villages and involved more heterogeneous actors to transform coral reef fisheries into sustainability as collective actions.

\section{References}

[1] Acheson, J. M. (2006). Institutional failure in resource management. Annual Review of Anthropology, 35, 117-134. https://doi.org/10.1146/annurev.anthro.35.081705.123238

[2] Armitage, D. (2008). Governance and the commons in a multi-level world. International Journal of the Commons, 2(1), 7-32. https://doi.org/10.1080/10826079308019552

[3] Armitage, D., Marschke, M., Plummer, R., \& et al. (2008). Adaptive co-management and the paradox of learning. Global Environmental Change, 18(1), 86-98. https://doi.org/10.1016/j.gloenvcha.2007.07.002

[4] Armitage, D. R., Plummer, R., Berkes, F., Arthur, R. I., Charles, A. T., Davidson-Hunt, I. J., Diduck, A. P., Doubleday, N. C., Johnson, D. S., Marschke, M., McConney, P., Pinkerton, E. W., \& Wollenberg, E. K. (2009). Adaptive co-management for social-ecological complexity. Frontiers in Ecology and the Environment, 7(2), 95-102. https://doi.org/10.1890/070089

[5] Aswani, S., Basurto, X., Ferse, S., Glaser, M., Campbell, L., Cinner, J. E., Dalton, T., Jenkins, L. D., Miller, M. L., Pollnac, R., Vaccaro, I., \& Christie, P. (2018). Marine resource 
management and conservation in the Anthropocene. Environmental Conservation, 45(2), 192-202. https://doi.org/10.1017/S0376892917000431

[6] Barnes, M. L., Mbaru, E., Muthiga, N., \& et al. (2019). Information access and knowledge exchange in co-managed coral reef fisheries. Biological Conservation, 238(108198). https://doi.org/https://doi.org/10.1016/j.biocon.2019.108198

[7] Berkes, F. (2006). From community-based resource management to complex systems: The scale issue and marine commons. Ecology and Society, 11(1). https://doi.org/10.5751/ES01431-110145

[8] Berkes, F. (2012). Implementing ecosystem-based management: Evolution or revolution? Fish and Fisheries, 13(4), 465-476. https://doi.org/10.1111/j.1467-2979.2011.00452.x

[9] Berkes, F., Feeny, D., McCay, B. J., \& Acheson, J. M. (1989). The benefits of the commons. Nature, 340, 91-93. https://doi.org/10.1038/340091a0

[10] Berkes, F., \& Folke, C. (1992). A systems perspective on the interrelations between natural, human-made and cultural capital. Ecological Economics, 5(1), 1-8. https://doi.org/10.1016/0921-8009(92)90017-M

[11] Berkes, F., Folke, C., \& Gadgill, M. (1994). Traditional Ecological Knowledge. In J. B. (eds) Perrings C.A., Mäler KG., Folke C., Holling C.S. (Ed.), Biodervisty Conservation (4th ed., pp. 269-287). Springer. https://doi.org/10.1007/978-94-007-0753-5_104248

[12] Bodin, Ö. (2017). Collaborative environmental governance: Achieving collective action in social-ecological systems. Science, 357(6352). https://doi.org/10.1126/science.aan1114

[13] Botto-Barrios, D., \& Saavedra-Diaz, L. M. (2020). Assessment of Ostrom's social-ecological system framework for the comanagement of small-scale marine fisheries in Colombia: from local fishers' perspectives. Ecology Society, 1(12). https://doi.org/. https://doi. org/10.5751/ES-11299-250112

[14] Bouzanis, C., \& Kemp, S. (2020). The two stories of the habitus/structure relation and the riddle of reflexivity: A meta-theoretical reappraisal. Journal for the Theory of Social Behaviour, 50(1), 64-83. https://doi.org/10.1111/jtsb.12225

[15] BPSPL. (2013). Monitoring Populasi dan Habitat Jenis Ikan Napoleon.

[16] BPSPL. (2015). Data Pembudidaya dan Jumlah Ikan Napoloen di Keramba.

[17] Bromley, D. W. (1992). The commons, common property, and environmental policy. Environmental and Resource Economics, 2(1), 1-17. https://doi.org/10.1007/BF00324686

[18] Buzelin, H. (2005). Unexpected allies: How Latour's network theory could complement Bourdieusian analyses in translation studies. Translator, 11(2), 193-218. https://doi.org/10.1080/13556509.2005.10799198

[19] Caetano, A. (2017). Coping With Life: A Typology of Personal Reflexivity. Sociological Quarterly, 58(1), 32-50. https://doi.org/10.1080/00380253.2016.1246904

[20] Carlsson, L., \& Berkes, F. (2005). Co-management: Concepts and methodological implications. Journal of Environmental Management, 75(1), 65-76. https://doi.org/10.1016/j.jenvman.2004.11.008

[21] Chuenpagdee, R., \& Jentoft, S. (2018). Transforming the governance of small-scale fisheries. $1,101-115$.

[22] CITES. (2017). CITES appendices I, II, III. Convention, January, 61. https://www.cites.org/eng/app/appendices.php

[23] Colding, J., \& Barthel, S. (2019). Exploring the social-ecological systems discourse 20 years later. Ecology and Society, 24(1). https://doi.org/10.5751/ES-10598-240102

[24] Creswell, J. W. (2013). Qualitative Inquire \& Research Design:Choosing Among Five Approaches. In SAGE (3rd ed., Vol. 53). 
International Journal of Social Science (IJSS)

Vol.1 Issue.5 February 2022, pp: 817-828

ISSN: 2798-3463 (Printed) | 2798-4079 (Online)

DOI: https://doi.org/10.53625/ijss.v1i5.1333

[25] Davis, R. A., \& Hanich, Q. (2020). Transparency in fisheries conservation and management measures. Marine Policy, June, 104088. https://doi.org/10.1016/j.marpol.2020.104088

[26] do Val, J. B. R., Guillotreau, P., \& Vallée, T. (2019). Fishery management under poorly known dynamics. European Journal of Operational Research, 279(1), 242-257. https://doi.org/10.1016/j.ejor.2019.05.016

[27] Foster, J. B. (2013). Marx and the Rift in the Universal metabolism of Nature. Monthly Review, 65(7). https://doi.org/DOI:10.14452/MR-065-07-2013-11_1

[28] Gardner, R., Ostrom, E., \& Walker, J. M. (1990). The Nature of Common-Pool Resource Problems. Rationality and Society, 2(3), 335-358. https://doi.org/10.1177/1043463190002003005

[29] Gurney, G. G., Darling, E. S., Jupiter, S. D., Mangubhai, S., McClanahan, T. R., Lestari, P., Pardede, S., Campbell, S. J., Fox, M., Naisilisili, W., Muthiga, N. A., D’agata, S., Holmes, K. E., \& Rossi, N. A. (2019). Implementing a social-ecological systems framework for conservation monitoring: lessons from a multi-country coral reef program. Biological Conservation, 240(August), 108298. https://doi.org/10.1016/j.biocon.2019.108298

[30] Hardin, G. (1968). The Tragedy of the Commons. Science, 162(3589), 1243-1248. https://doi.org/10.1126/science.162.3859.1243

[31] Hayes, A. S. (2020). The Behavioral Economics of Pierre Bourdieu. Sociological Theory, 38(1), 16-35. https://doi.org/10.1177/0735275120902170

[32] IUCN. (2004). The IUCN Red List of Threatened Species: Cheilinus undulatus, Humphead Wrasse (Vol. 8235). https://doi.org/10.2305/IUCN.UK.2004.RLTS.T4592A11023949.en

[33] Jentoft, S. (1989). Fisheries co-management: Delegating governmnet responsibility to fishermen's organizations. Marine Policy, 3(2), 137-154. https://doi.org/10.1016/0308$597 X(89) 90004-3$

[34] Jentoft, S. (2000). The community: A missing link of fisheries management. Marine Policy, 24(1), 53-60. https://doi.org/10.1016/S0308-597X(99)00009-3

[35] Jentoft, S. (2007). In the power of power: The understated aspect of fisheries and coastal management. Human Organization, 66(4), 426-437. https://doi.org/10.17730/humo.66.4.a836621h2k5x46m2

[36] Jupiter, S. D., Cohen, P. J., Weeks, R., Tawake, A., \& Govan, H. (2014). Locally-managed marine areas: Multiple objectives and diverse strategies. Pacific Conservation Biology, 20(2), 165-179. https://doi.org/10.1071/PC140165

[37] Kawaka, J. A., Samoilys, M. A., Murunga, M., Church, J., Abunge, C., \& Maina, G. W. (2017). Developing locally managed marine areas: Lessons learnt from Kenya. Ocean and Coastal Management, 135, 1-10. https://doi.org/10.1016/j.ocecoaman.2016.10.013

[38] Khasanah, M., Nurdin, N., Sadovy de Mitcheson, Y., \& Jompa, J. (2020). Management of the Grouper Export Trade in Indonesia. Reviews in Fisheries Science and Aquaculture, 28(1), 1-15. https://doi.org/10.1080/23308249.2018.1542420

[39] Klinger, D., \& Naylor, R. (2012). Searching for solutions in aquaculture: Charting a sustainable course. Annual Review of Environment and Resources, 37, 247-276. https://doi.org/10.1146/annurev-environ-021111-161531

[40] Kockel, A., Ban, N. C., Costa, M., \& Dearden, P. (2019). Evaluating approaches for scalingup community-based marine-protected areas into socially equitable and ecologically representative networks. Conservation Biology, 34(1), 1-11. https://doi.org/10.1111/cobi.13368 
[41] Korten, D. C. (1987). Third generation NGO strategies: A key to people-centered development. World Development, 15(1), 145-159. https://doi.org/https://doi.org/10.1016/0305-750X(87)90153-7

[42] Latour, B. (1999). LATOUR on recalling ANT. The Sociological Review, 47(1), 15-25. https://doi.org/10.1111/j.1467-954X.1999.tb03480.x

[43] Lowerre-Barbieri, S. K., Kays, R., Thorson, J. T., \& Wikelski, M. (2019). The ocean's movescape: Fisheries management in the bio-logging decade (2018-2028). ICES Journal of Marine Science, 76(2), 477-488. https://doi.org/10.1093/icesjms/fsy211

[44] Luyapaert, T., Hagan, J. G., McCarthy, M. L., \& Poti, M. (2018). Status of Marine Biodiversity in the Anthropocene. In S. Jungblut, V. Liebich, \& M. Bode-Dalby (Eds.), YOUMARES 9 - The Oceans: Our Research, Our Future (pp. 57-82). Springer Open. https://doi.org/10.1007/978-3-030-20389-4_13

[45] Lynch, A. J., Cooke, S. J., Beard, T. D., Kao, Y. C., Lorenzen, K., Song, A. M., Allen, M. S., Basher, Z., Bunnell, D. B., Camp, E. V., Cowx, I. G., Freedman, J. A., Nguyen, V. M., Nohner, J. K., Rogers, M. W., Siders, Z. A., Taylor, W. W., \& Youn, S. J. (2017). Grand Challenges in the Management and Conservation of North American Inland Fishes and Fisheries. Fisheries, 42(2), 115-124. https://doi.org/10.1080/03632415.2017.1259945

[46] Milner, C., Currier, K., Kopcho, B., \& Alling, A. (2013). A status report on the coral reef at Pulau Durai, Anambas Islands, Indonesia. Atoll Research Bulletin, 591, 1-17. https://doi.org/10.5479/si.00775630.591

[47] Mujiyanto, M., Sugianti, Y., Garcia, M. G., \& Edrus, I. N. (2020). Institutional restructuring of fisheries management system for humphead wrasse (Cheilinus undulatus R PPELL 1835) in Anambas and Natuna, Riau Archipelago Province, Indonesia. IOP Conference Series: Earth and Environmental Science, 584(1), 0-10. https://doi.org/10.1088/1755$1315 / 584 / 1 / 012003$

[48] Ostrom, E. (1990). Governing the Commons: The evolution of institutions for collective cction (J. E. Alt \& D. C. North (eds.)). Cambridge University Press. https://doi.org/10.1017/CBO9780511807763

[49] Ostrom, E. (1991). Rational Choice Theory and Institutional Analysis: Toward Complementarity. American Political Science Review, 85(1), 237-243. https://doi.org/10.2307/1962888

[50] Ostrom, E. (2009). A General Framework for Analyzing Sustainability of Social-Ecological Systems. Science, 325(July), 419-421. https://doi.org/10.1126/science.1172133

[51] Pitcher, T. J., \& Lam, M. E. (2010). Fishful thinking: Rhetoric, reality, and the sea before us. Ecology and Society, 15(2), 25. https://doi.org/10.5751/ES-03320-150212

[52] Pomeroy, R., Parks, J., Mrakovcich, K. L., \& LaMonica, C. (2016). Drivers and impacts of fisheries scarcity, competition, and conflict on maritime security. Marine Policy, 67, 94-104. https://doi.org/10.1016/j.marpol.2016.01.005

[53] Roberson, L. A., Watson, R. A., Klein, C. J., \& et al. (2020). Over 90 endangered fish and invertebrates are caught in industrial fisheries. Nature Communications, 11(1), 1-8. https://doi.org/10.1038/s41467-020-18505-6

[54] Sadovy de Mitcheson, Y. (2019). Live Reef Food Fish Trade: Undervalued, Overfished and Opportunities. https://www.icriforum.org/wp-content/uploads/2020/05/ICRI Live Reef Food Fish Report-44p-double_0.pdf

[55] Sadovy de Mitcheson, Y., Andersson, A. A., Hofford, A., Law, C. S. W., Hau, L. C. Y., \& Pauly, D. (2018). Out of control means off the menu: The case for ceasing consumption of luxury products from highly vulnerable species when international trade cannot be 
International Journal of Social Science (IJSS)

Vol.1 Issue.5 February 2022, pp: 817-828

ISSN: 2798-3463 (Printed) | 2798-4079 (Online)

DOI: https://doi.org/10.53625/ijjs.v1i5.1333

adequately controlled; shark fin as a case study. Marine Policy, 98(September), 115-120. https://doi.org/10.1016/j.marpol.2018.08.012

[56] Sadovy de Mitcheson, Y., Linardich, C., Barreiros, J. P., Ralph, G. M., Aguilar-Perera, A., Afonso, P., Erisman, B. E., Pollard, D. A., Fennessy, S. T., Bertoncini, A. A., Nair, R. J., Rhodes, K. L., Francour, P., Brulé, T., Samoilys, M. A., Ferreira, B. P., \& Craig, M. T. (2020). Valuable but vulnerable: Over-fishing and under-management continue to threaten groupers so what now? Marine Policy, 116(August 2019). https://doi.org/10.1016/j.marpol.2020.103909

[57] Sadovy, Y., Kulbicki, M., Labrosse, P., Letourneur, Y., Lokani, P., \& Donaldson, T. J. (2004). Erratum: The humphead wrasse, Cheilinus undulatus: Synopsis of a threatened and poorly known giant coral reef fish (Reviews in Fish Biology and Fishiries (2003) vol. 13 (327-364). Reviews in Fish Biology and Fisheries, 13(4), 459. https://doi.org/10.1007/s11160-004-1885-0

[58] Sherman, K. D., Shultz, A. D., Dahlgren, C. P., Thomas, C., Brooks, E., Brooks, A., Brumbaugh, D. R., Gittens, L., \& Murchie, K. J. (2018). Contemporary and emerging fisheries in The Bahamas-Conservation and management challenges, achievements and future directions. Fisheries Management and Ecology, 25(5), 319-331. https://doi.org/10.1111/fme.12299

[59] Shin, H. C., Yu, D. J., Park, S., Anderies, J. M., Abbott, J. K., Janssen, M. A., \& Ahn, T. K. (2020). How do resource mobility and group size affect institutional arrangements for rule enforcement? A qualitative comparative analysis of fishing groups in South Korea. $\begin{array}{llll}\text { Ecological Economics, } & \text { 174(August } & 2019 \text { ), }\end{array}$ https://doi.org/10.1016/j.ecolecon.2020.106657

[60] Soemodinoto, A., Djunaidib, A., Nur, J. M., \& et al. (2013). Budidaya Ikan Napoleon oleh Masyarakat di Kepulauan Anambas, Provinsi Kepulauan Riau : Evolusi Kegiatan, Jejaring Pembudidaya dan Kelayakan Usaha (Issue December). https://www.researchgate.net/publication/274634053_Budidaya_Ikan_Napoleon_oleh_Mas yarakat_di_Kepulauan_Anambas_Provinsi_Kepulauan_Riau_Evolusi_Kegiatan_Jejaring_P embudidaya_dan_Kelayakan_Usaha

[61] Wacquant, L. (2001). Durkheim and Bourdieu: The Common Plinth and its Cracks. The Sociological Review, 49(1_suppl), 105-119. https://doi.org/10.1111/j.1467954x.2001.tb03536.x

[62] Weng, K. C., Pedersen, M. W., Del Raye, G. A., Caselle, J. E., \& Gray, A. E. (2015). Umbrella species in marine systems: Using the endangered humphead wrasse to conserve coral reefs. Endangered Species Research, 27(3), 251-263. https://doi.org/10.3354/esr00663 
